\title{
RECENT EVOLUTIONS OF NATURAL FOCI OF LEPTOSPIROSIS AND SMALL MAMMAL COMMUNITIES (RODENTIA, INSECTIVORA) IN THE REPUBLIC OF MOLDOVA
}

\author{
Victoria BURLACU \\ National Agency for Public Health Chisinau, Republic of Moldova, \\ Institute of Zoology, Chisinau, Republic of Moldova
}

Corresponding author: Victoria Burlacu, e-mail: burlacu.ivictoria@gmail.com

DOI: $10.38045 /$ ohrm.2020.1.13

UDC: 616.98:579.834.115:599.32/.38(478)

Keywords: small mammals, Leptospira spp., leptospirosis, ecosystem, biotope.

Cuvinte cheie: mamifere mici, Leptospira spp., leptospiroza, ecosistem, biotop.
Introduction. Leptospirosis is a zoonosis caused by microorganisms of the genus Leptospira with a global spread. The main reservoir of leptospires are the small mammals, which survive after infection, spreading the causative agent in the environment with urine.

Material and methods. The studied were conducted in 2017-2019 in different ecosystems, where 1617 small mammals were collected, investigated for the presence of specific antibodies to Leptospira spp. Ecological analysis of small mammal communities was performed and leptospire-carrier species were identified.

Results. 17 species of the order Rodentia and Soricomorpha were identified. The most widespread are A. sylvaticus, A. flavicollis and A. agrarius with a frequency of 100\%, abundant and dominant in most of the studied ecosystems. Antibodies specific to Leptospira spp. were detected in 9 species, the highest share of the species with leptospire belongs to A. agrarius (53.85\%) and C. glareolus (11.54\%). The serogroups Leptospira grippotyphosa, L. icterohaemorrhagiae and L. pomona were highlighted.

Conclusions. The epizootiological process in leptosrosis is mentained active in the nature by 9 species of small mammals, including one of the euritope species A. agrarius, the leptospire rate was determined at 53.85\%. The intense circulation of leptospires in the small mammal population determines the need to monitor the multiannual dynamics of their in order to establish changes in natural foci of leptospirosis, forecast the epizootological situation and the risk of spreading of disease among the human population.

EVOLUTIILE RECENTE A FOCARELOR NATURALE DE LEPTOSPIROZĂ ȘI COMUNITĂȚILE MAMIFERELOR MICI (RODENTIA, INSECTIVORA) ÎN REPUBLICA MOLDOVA

Introducere. Leptospiroza este o zoonoză cauzată de microorganismele din genul Leptospira cu o răspândire globală. Rezervorul de bază al leptospirelor sunt mamiferele mici care după infectare supravieţuiesc, diseminând agentul cauzal în mediul înconjurător prin urină.

Material și metode. Cercetările au fost efectuate în perioada 2017-2019 în diverse ecosisteme, de unde au fost colectate 1617 mamifere mici, care au fost investigate la prezența anticorpilor specifici Leptospira spp. S-a efectuat analiza ecologică a comunităților de mamifere mici și identificate speciile purtătoare de leptospire.

Rezultate. Au fost identificate 17 specii din ordinul Rodentia și Soricomorpha. Cele mai răspândite sunt A. sylvaticus, A. flavicollis și A. agrarius cu o frecvență de $100 \%$, fiind abundente și dominante în majoritatea ecosistemelor cercetate. Anticorpi specifici la Leptospira spp. s-au evidențiat la 9 specii, dintre care cea mai înaltă pondere îi revine speciei $A$. agrarius (53,85\%) și C. glareolus (11,54\%). S-au evidențiat serogrupele Leptospira grippotyphosa, L. icterohaemorrhagiae și L. pomona.

Concluzii. Procesul epizootologic la leptosroză este menținut activ în natură de 9 specii de mamifere mici, inclusiv la una din speciile euritope A. agrarius s-a determinat portajul de leptospire în cote de 53,85\%. Circulația intensa a leptospirelor în populația mamiferelor mici determină necesitatea monitorizării în dinamică multianuală a acestora pentru stabilirea modificărilor in focarele naturale de leptospiroză, prognozarea situației epizootologice și riscului de răspândire a bolii în populația umană. 


\section{INTRODUCTION}

Leptospirosis is a zoonosis caused by representatives of the genus Leptospira with a global spread, which affects the human population on continents with tropical and temperate climates. It occurs in urban areas of industrialized and developing countries, as well as in rural areas around the world. This disease is recognized as an emerging global public health problem, due to the increased incidence in many economically advanced and developing countries. For the first time, living leptospires were observed under dark-field microscopy, during the examination of a water sample from a pool, an observation communicated in 1914 by Wolbach and Binger. After the discovery of leptospires, the Japanese researchers (1) described the role of rats as carriers of the causative agent of leptospirosis, which led to the establishment of the mechanism and ways of transmission of the causative agent from animals to humans. The representatives of the genus Leptospira persist in the kidneys and genital tract of carrier animals and are excreted in the urine. Human infection occurs accidentally, through direct contact with the infected animal, or indirectly through contaminated environment, such as soil or water (1-8).

The leptospire reservoir includes a large number of species of wild and domestic animals (cattle and pigs) that survive infection with the causative agent of leptospirosis, spreading the causative agent in the environment for a long time with urine. All terrestrial mammals can be indicated as a source of leptospira, but the most important species are those from the orders Rodentia and Insectivora, which can be true living environments particularly favorable for hosting, multiplying and eliminating leptospires in the environment. A potential risk of human infection is maintained in the territories where leptospirecarrying status have been recorded in wild animals, and in domestic animals - diseases or asymptomatic state. These territories are considered as foci of leptospirosis and, depending on the reservoir, can be classified into natural and anthropogenic $(1-6,9,10,11)$.

According to literature data, as a reservoir and source of leptospira infection the orders Marsupialia, Insectivora, Chiroptera, Primates, Edentata, Lagomorpha, Rodentia, Carnivora and Artiodactyla are of major importance, which are taxonomically included in the class of mammals, but the main carriers are the representatives of 4 orders: Marsupialia, Insectivora, Rodentia and Carnivora. At the same time not all the species of an order are carriers of leptospires. As a reservoir of leptospires a significant role was assigned to mammals of the order Rodentia - 20\%, Marsupialia - 39\% and Chiroptera - 35\% (12). The role of the species Mus musculus and Rattus norvegicus as a reservoir and source of leptospires is well known in Portugal, Azores (13). It is known that small mammals are indispensable elements of terrestrial ecosystems and are important links in the food chains of the living world. Most species of small mammals, especially rodents, are very prolific, reach high densities in various types of ecosystems and have wide limits of ecological valence. All these peculiarities favor the wide spread of this group of mammals and their rapid adaptation to anthropogenic and environmental changes (14-17). In France, the beaver (Myocastor coypus) is involved in the spread of leptospirosis, a species that inhabits clean stagnant waters and is common in the last decade. The seroprevalence of leptospires in the population of Myocastor coypus varied from $16.5 \%$ to $66.0 \%$, being detected the serogroups: L. icterohaemorrhagiae and L. sejroe (18). In Germany, the wild boar (Sus scrofa) has been identified as the possible source of leptospirosis infection, a fact confirmed by a number of European researchers who have highlighted the serogroup L. pomona, frequently isolated from domestic pigs and wild boars (19).

In the Republic of Moldova, the study of leptospirosis began in the 1950s, where leptospirosis was first established in cattle in Tiraspol city, and then the disease was recorded in pigs, horses and cattle in all districts of the republic. Later, during 1969-1971, natural outbreaks of leptospirosis were registered in the northern area, with the involvement in the epizootic process of Microtus species and the etiological agent Leptospira grippotyphosa. During 1987-1988 when 2 cases of leptospirosis were registered in the workers of a meat processing plant, as a source of leptospirosis infection the brown rat was established, in which specific antibodies to the serogroup L. icterohaemorrhagiae were highlighted (20). Another outbreak of leptospirosis was recorded in 1996 in 7 fishermen from the local fish farm of Costesti village, Ialoveni district and it was shown that the source of infection were the small mammals, in which the serogroup 
L. icterohaemorrhagiae was reported (21). Studies conducted during 2006-2008 demonstrated that in the leptospirosis foci the infection reservoir are the species of the order Rodentia, where the highest share of positive results in leptospirosis was found in Rattus norvegicus (37.7\%), Apodemus sylvaticus (21.8\%) and A. agrarius (20.9\%) (9). During this period, positive serological results were established in 10 species of the order Rodentia (Muscardinus avellanarius, Clethrionomys glareolus, $A$. terrestris, Microtus sp., $A$. uralensis, A. sylvaticus, A. flavicollis, A. agrarius, Mus musculus, $R$. norvegicus) and 2 species of the order Insectivora (Sorex minutus, S. araneus). Studies conducted in our country showed that the main source of infection is rodents, and human infection occurs both during bathing, using water from unauthorized sources in the field and after using food contaminated by rodents $(9,10$, 20, 21-25).

The study of the ecological peculiarities of small mammals in leptospirosis outbreaks aims to elucidate the species involved in the epizootic process, followed by determining the etiological structure of circulating leptospirosis in the ecosystems of the Republic of Moldova. The data obtained are used to develop epizootic prognoses, public health risk assessment and argumentation of disease prevention and control measures.

\section{MATERIAL AND METHODS}

The studies were conducted during 2017-2019 in the North, Center and South of the Republic of Moldova, districts Glodeni, Edinet, Ocnita, Orhei, Ialoveni, Chisinau, Cahul and Stefan Voda, in 147 natural and anthropogenic biotopes that were grouped in 6 types: forest, paludous, agrocenoses, forest belt, forest edge and rural-paludous ecotone. The data are presented for winter spring (December, February-May) and summerautumn (June - November) periods. Snap traps were used to collect small mammals baited with pieces of bread soaked in sunflower oil. The traps were installed either in line or randomly, with the distance of 7-10 m between the traps. About 40-50 traps were used per biotope and only the functional ones were taken into account (26). A total of 8593 night-traps were processed, 1617 small mammals were captured and 1572 individuals were investigated for the presence of specific antibodies to Leptospira spp. in the microbiological laboratory within the National Agency for Public Health. Each individual was identified, except for sibling species of the genus Microtus (M. arvalis and M. rossiaemerdionalis), which were considered as Microtus sp.

The ecological analysis of small mammal communities was performed using the indexes of capture (Ic), abundance (A), frequency (F), diversity (Shannon, $\mathrm{H}^{\prime}$; Simpson) and dominance (Naughton-Wolf, $I_{d}$ ). The ecological significance (Wa) of the species in studied ecosistems was assessed. The statistical analysis and graphic presentation of the results were performed via the Microsoft Excel and BioDiversity Pro Programs. The data for the Statistical Report regarding the morbidity caused by leptospirosis in the Republic of Moldova for 2017-2019 were processed.

\section{RESULTS}

A total of 1617 small mammals were collected, 13 species of the order Rodentia: M. glis, A.sylvaticus, A. flavicollis, A. uralensis, A. agrarius, Mus spicilegus, $M$. musculus, $R$. norvegicus, $M$. minutus, Microtus sp., M. subterranus, C. glareolus, A. terrestris and 4 species of the order Soricomorpha: S. minutus, S. araneus, C.suaveolens and N. anomalus.

The capture index of small mammals varied depending on the year, season and geographical area. In the study period 2017-2019, the average multiannual capture index was 18.81\%. In 2017 this index was the highest (23.37\%), compared to $2018(17.38 \%)$ and $2019(12.77 \%)$.

In the northern area 808 small mammals were collected from 10 rodents species: A. sylvaticus, A. flavicollis, A. uralensis, A. agrarius, M. spicilegus, M. musculus, $R$. norvegicus, M. minutus, Microtus sp., M. subterranus și $C$. glareolus and 4 shrew species: $S$. minutus, $S$. araneus, $C$. suaveolens and $N$. anomalus (tab.1). For the period of 2017-2019, the multiannual average capture index was 24.92\%. In 2017 this index was $30.61 \%$, in $2018-18.62 \%$ and in $2019-11.90 \%$. The highest multiannual average capture index was recorded in the rural-poaludosu ecotone $(62.4 \%)$ and very close values were recorded in the paludous biotope and forest belt $(30.52 \%$ $30.83 \%$ ), while the lowest index was in forests and at forest edge (17.42\%-17.83\%) (tab.1). 
The total diversity of small mammal species according to the Shannon index was 0.643 and the Simpson index -4.225 . The greatest diversity was registered in the forest belt $(0.793 ; 4.182)$, agrocenosis $(0.782 ; 3.783)$ and paludous $(0.714$; 4.007) biotopes with the dominant species $A$. flavicollis $\left(\mathrm{I}_{\mathrm{d}}-86.40 \%\right)$ and A agrarius $\left(\mathrm{I}_{\mathrm{d}}-\right.$ $73.94 \%-90.85 \%$ ), which constituted more than half of the small mammal community. The lowest values of diversity were recorded in the forest biotopes $(0.569 ; 1,801)$, the dominant being $A$. flvicollis (80\%) (tab.1).
Throughout the study period, the dominant species of $A$. sylvaticus, $A$. flavicollis and $A$. agrarius were the most widespread and present in all the biotopes with a frequency of $100 \%$. A. sylvaticus was abundant in forest belt and rural-paludous ecotone with eudominant ecological significance, and low values of abundance in forest with a dominant significance. A. flavicollis was abundant in forest, forest edge and forest belt with eudominant ecological significance, and low values of abundance in agrocenoses and rural-paludous ecotone (about 6\%) with dominant significance (tab.1).

Table 1. Abundance (A), ecological significance (Wa) and diversity of small mammal species in studied ecosystems from the northern area of the Republic of Moldova.

\begin{tabular}{|c|c|c|c|c|c|c|c|c|c|c|c|c|c|c|}
\hline \multirow[t]{2}{*}{ No. } & \multirow[t]{2}{*}{ Species } & \multicolumn{2}{|c|}{ Forest } & \multicolumn{2}{|c|}{ Agrocenosis } & \multicolumn{2}{|c|}{ Paludous } & \multicolumn{2}{|c|}{ Forest edge } & \multicolumn{2}{|c|}{ Shelter belt } & \multicolumn{2}{|c|}{$\begin{array}{c}\text { Rural- } \\
\text { paludous }\end{array}$} & \multirow{2}{*}{$\begin{array}{c}\text { Total } \\
\mathrm{A}\end{array}$} \\
\hline & & A & $\mathrm{Wa}$ & A & $\mathrm{Wa}$ & A & $\mathrm{Wa}$ & A & Wa & A & $\mathrm{Wa}$ & A & $\mathrm{Wa}$ & \\
\hline 1 & S. araneus & 2.36 & 1.57 & 2.42 & 1.61 & 2.45 & 1.64 & 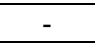 & - & 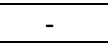 & - & 4.76 & 3.17 & 1.61 \\
\hline 2 & S. minutus & - & - & - & - & 1.84 & 0.61 & - & - & - & - & 1.59 & 0.53 & 0.50 \\
\hline 3 & C. suaveolens & - & - & - & - & - & - & 0.54 & 0.09 & - & - & - & - & 0.12 \\
\hline 4 & N. anomalus & - & - & - & - & 0.61 & 0.10 & - & - & - & - & - & - & 0.12 \\
\hline 5 & A. sylvaticus & 5.51 & 5.51 & 16.94 & 16.94 & 9.20 & 9.20 & 25.41 & 25.4 & 8.22 & 8.22 & 20.63 & 20.63 & 14.23 \\
\hline 6 & A. flavicollis & 73.2 & 73.23 & 6.45 & 6.45 & 20.86 & 20.86 & 32.97 & 32.97 & 49.32 & 49.32 & 6.35 & 6.35 & 33.66 \\
\hline 7 & A. uralensis & - & - & 11.29 & 3.76 & 2.45 & 0.82 & - & - & - & - & - & - & 2.23 \\
\hline 8 & A. agrarius & 11.8 & 11.81 & 45.97 & 45.97 & 42.94 & 42.94 & 23.24 & 23.2 & 24.66 & 24.66 & 46.03 & 46.03 & 30.94 \\
\hline 9 & M. spicilegus & - & - & 968 & 3.23 & - & - & 11.89 & 3.96 & - & - & - & - & 4.21 \\
\hline 10 & M. musculus & - & - & 1.61 & 0.81 & - & - & - & - & 0.68 & 0.34 & 1.59 & 0.79 & 0.50 \\
\hline 11 & R. norvegicus & - & - & - & - & 1.23 & 0.41 & - & - & - & - & 1.59 & 0.53 & 0.37 \\
\hline 12 & M. minutus & - & - & - & - & 0.61 & 0.20 & - & - & - & - & 1.59 & 0.53 & 0.25 \\
\hline 13 & Microtus sp. & - & - & 5.65 & 4.70 & 9.82 & 8.18 & 3.243 & 2.7 & 2.05 & 1.71 & 1.59 & 1.32 & 4.08 \\
\hline 14 & M.subterraneus & - & - & - & - & - & - & - & - & 4.11 & 1.37 & 1.59 & 0.53 & 0.87 \\
\hline 15 & C. glareolus & 7.09 & 5.91 & - & - & 7.98 & 6.65 & 2.70 & 2.25 & 10.96 & 9.13 & 12.70 & 10.58 & 6.31 \\
\hline \multicolumn{2}{|c|}{ Capture index, \% } & \multicolumn{2}{|c|}{17.42} & \multicolumn{2}{|c|}{26.96} & \multicolumn{2}{|c|}{30.52} & \multicolumn{2}{|c|}{30.83} & \multicolumn{2}{|c|}{17.83} & \multicolumn{2}{|c|}{62.38} & 24.92 \\
\hline \multicolumn{2}{|c|}{ Shannon index } & \multicolumn{2}{|c|}{0.569} & \multicolumn{2}{|c|}{0.782} & \multicolumn{2}{|c|}{0.714} & \multicolumn{2}{|c|}{0.793} & \multicolumn{2}{|c|}{0.713} & \multicolumn{2}{|c|}{0.692} & 0.643 \\
\hline \multicolumn{2}{|c|}{ Simpson index } & \multicolumn{2}{|c|}{1.801} & \multicolumn{2}{|c|}{3.783} & \multicolumn{2}{|c|}{4.007} & \multicolumn{2}{|c|}{4.182} & \multicolumn{2}{|c|}{3.122} & \multicolumn{2}{|c|}{3.749} & 4.225 \\
\hline
\end{tabular}

A. agrarius had the highest abunance in agrocenosis, paludous and rural-paludous biotopes with eudominant ecological significance. $A$. uralensis with a frequency of $33.33 \%$ was registered in agrocenosis with dominant ecological significance and in paludous biotope with recedent significance (tab.1).

The forest vole species $C$. glareolus was registered in all type of biotopes except the agrocenosis with a frequrency of $83.33 \%$ and dominant ecological significance, while M. subteraneus was recorded at forest edge and in rural-paludous ecotone with $33.33 \%$ frequency and recedent or subrecedent signify cance. The field voles Microtus sp. were mostly spread in all types of biotopes, except the forest ones, showing a dominant ecological significance in agrocenosisi and paludous biotopes, and with subdominant significance in other habitats (tab.1; fig.1).

M. musculus is a typical synanthropic species and was registered in anthropyzed biotopes with $50 \%$ frequency, low abundance and subrecedent significance. M. spicilegus (F-33.33\%) was recorded in agrocenosis and at forest edge near agrocenoses with recedent ecological significance. The species $R$. norvegicus and $M$. minutus had the same biotopic distribution and subrecedent ecological significance (tab.1; fig,1).

Among shrews, the most spread was $S$. araneus (F-66.67\%) with recedent ecological significance. Other three species were observed only in paludous biotopes (S. minutus, $N$. anomalus) or at forst edge ( $C$. suaveolens) with subrecedent ecological significance (tab.1; fig.1). 
In the central area, 479 small mammals were collected from 13 species: M. glis, A. sylvaticus, $A$. flavicollis, A. uralensis, A. agrarius, M. spicilegus, M. musculus, $R$. norvegicus, M. minutus, Microtus sp., M. subterraneus, $C$. glareolus and $S$. araneus (tab.2). The average multiannual capture index for the study period was 14.83\%. In 2017 the capture index was $13.70 \%$, in 2018 - 18.11\% and in 2019 the lowest index - 12.98\%. The highest multiannual average catch index was recorded in the agrocenosis $(21.55 \%)$ and at forest edge (16.26\%), and the lowest index was reported in the paludous biotope $(10.25 \%)$ (tab.2).

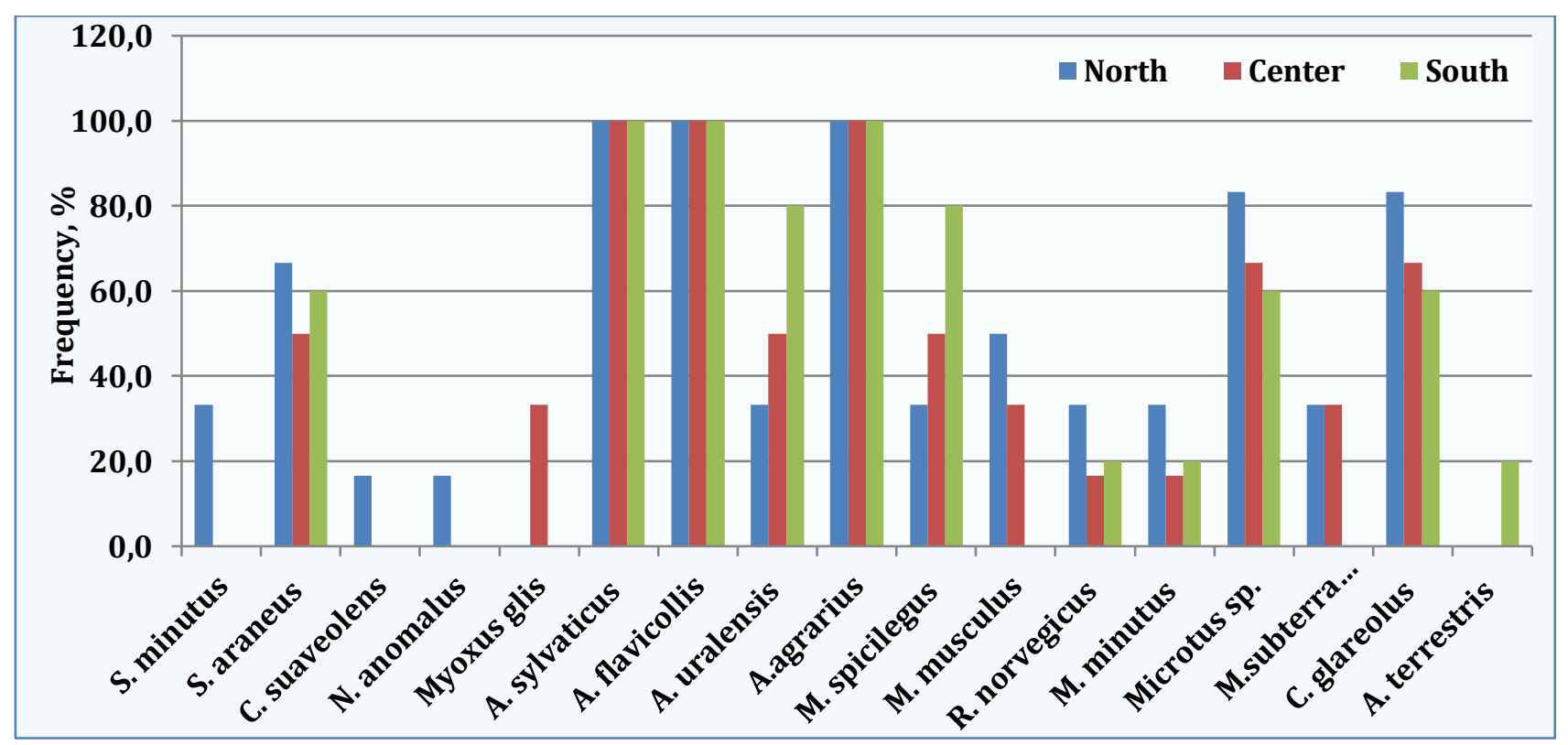

Figure 1. Frequency (\%) of small mammal species in studied ecosystems from the northern, central and southern areas of the Republic of Moldova.

The total diversity of small mammal species according to Shannon index was 0.744 and the Simpson index -5.064 . The greatest diversity of species was recorded in the agrocenosis $(0.854$; $5.317)$ and forest belt $(0.816 ; 4.29)$, and the lowest diversity - in the forest $(0.543 ; 2.102)$, similar with the results obtained in the northern area (tab.2).

The dominant species of $A$. sylvaticus, $A$. flavicollis and $A$. agrarius, found in the northern area were present in all studied biotopes with a frequency of $100 \%$. A. sylvaticus was more abundant and do-minant in agrocenosis $\left(\mathrm{I}_{\mathrm{d}}-62.94 \%\right)$ and in forest belt $\left(\mathrm{I}_{\mathrm{d}}-56.14 \%\right)$ with eudominant ecological significance. A. flavicollis was more abundant and dominant in forest biotopes $\left(\mathrm{I}_{\mathrm{d}}-\right.$ $84.35 \%)$ and at forest edge $\left(I_{d}-57.67 \%\right)$ with eudominant ecological significance, while in the paludous biotope, it had a low abundance and a recedent significance. A. agrarius was most abundant and dominant in the paludous biotope $\left(\mathrm{I}_{\mathrm{d}}-68 \%\right)$ and in the rural-paludous ecotone $\left(\mathrm{I}_{\mathrm{d}^{-}}\right.$ $40.91 \%$ ) with eudominat significance. The spe- cies $A$. uralensis with a frequency of $50 \%$ was reported in agrocenosis and forest belt with dominant ecological significance (tab.2; fig.1).

The voles Microtus sp. and C. glareolus had a frequency of $66.67 \%$ and $M$. subterraneus had a $33.33 \%$ frequency, recorded only in forest biotopes with recedent ecological significance. $M$. spicilegus showed a dominant ecological significance in agrocenosis, whereas the M. musculus had a dominant ecological significance in ruralpaludous ecotone. The species of $M$. minutus and $R$. norvegicus were recorded only in ruralpaludous ecotone (F-16.67\%) with recedent ecological significnance (tab. 2; fig. 1).

The shrew of $S$. araneus had a $50 \%$ frequency, showing a dominant ecologcal significance in paludous biotopes and a recedent significance at forest edge (tab.2; fig.1).

In the southern area, 329 small mammals from 11 species were collected: $A$. sylvaticus, $A$. flavicollis, A. uralensis, A. agrarius, M. spicilegus, M. musculus, $R$. norvegicus, M. minutus, Microtus sp., C. glareolus and S. araneus (tab.3). 
Table 2. Abundance (\%), ecological significance (Wa) and diversity of small mammal species in studied ecosystems from the central area of the Republic of Moldova.

\begin{tabular}{|c|c|c|c|c|c|c|c|c|c|c|c|c|c|}
\hline \multirow[t]{2}{*}{ Species } & \multicolumn{2}{|c|}{ Forest } & \multicolumn{2}{|c|}{ Agrocenosis } & \multicolumn{2}{|c|}{ Paludous } & \multicolumn{2}{|c|}{ Forest edge } & \multicolumn{2}{|c|}{ Shelter belt } & \multicolumn{2}{|c|}{$\begin{array}{c}\text { Rural- } \\
\text { paludous }\end{array}$} & \multirow{2}{*}{$\frac{\text { Total }}{\mathrm{A}}$} \\
\hline & $\mathrm{A}$ & Wa & $\mathrm{A}$ & Wa & $\mathrm{A}$ & $\mathrm{Wa}$ & $\mathrm{A}$ & $\mathrm{Wa}$ & $\mathrm{A}$ & $\mathrm{Wa}$ & $\mathrm{A}$ & $\mathrm{Wa}$ & \\
\hline 1 S. araneus & - & - & 2.11 & 1.06 & 12.00 & 6.00 & - & - & 1.52 & 0.76 & - & - & 1.46 \\
\hline 2 M.glis & 0.87 & 0.29 & - & - & - & - & 6.09 & 5.36 & - & - & - & - & 3.13 \\
\hline 3 A. sylvaticus & 18.26 & 18.26 & 27.46 & 27.46 & 8.00 & 8.00 & 36.78 & 36.78 & 16.67 & 16.67 & 11.36 & 11.36 & 22.96 \\
\hline 4 A. flavicollis & 66.09 & 66.09 & 23.94 & 23.94 & 4.00 & 4.00 & 4.60 & 4.60 & 62.12 & 57.67 & - & - & 32.57 \\
\hline 5 A. uralensis & - & - & 17.61 & 8.80 & - & - & 13.79 & 6.90 & - & - & 4.55 & 2.27 & 8.14 \\
\hline 6 A. agrarius & 0.87 & 0.87 & 9.86 & 9.86 & 56.00 & 56.00 & 24.14 & 24.14 & 6.06 & 6.06 & 56.82 & 56.82 & 16.49 \\
\hline 7 M. spicilegus & - & - & 13.38 & 6.69 & - & - & - & - & 1.52 & 0.76 & - & - & 4.80 \\
\hline 8 M. musculus & - & - & 1.41 & 0.47 & - & - & - & - & - & - & 15.91 & 5.30 & 1.88 \\
\hline 9 M. minutus & - & - & - & - & - & - & - & - & - & - & 4.55 & 0.76 & 0.42 \\
\hline 10 R. norvegicus & - & - & - & - & - & - & - & - & - & - & 2.27 & 0.38 & 0.21 \\
\hline 11 Microtus sp. & - & - & 4.23 & 2.82 & 12.00 & 8.00 & - & - & 1.52 & 1.01 & 4.55 & 3.03 & 2.51 \\
\hline 12 M.subterraneus & 1.74 & 0.58 & - & - & - & - & 3.45 & 1.15 & - & - & - & - & 1.04 \\
\hline 13 C. glareolus & 9.57 & 6.38 & - & - & 8.00 & 5.33 & 1.15 & 0.77 & 10.61 & 7.07 & - & - & 4.38 \\
\hline Capture index, \% & \multicolumn{2}{|c|}{12.53} & \multicolumn{2}{|c|}{21.55} & \multicolumn{2}{|c|}{10.25} & \multicolumn{2}{|c|}{13.41} & \multicolumn{2}{|c|}{16.26} & \multicolumn{2}{|c|}{12.39} & 14.83 \\
\hline Shannon index & \multicolumn{2}{|c|}{0.543} & \multicolumn{2}{|c|}{0.854} & \multicolumn{2}{|c|}{0.763} & \multicolumn{2}{|c|}{0.816} & \multicolumn{2}{|c|}{0.613} & \multicolumn{2}{|c|}{0.703} & 0.744 \\
\hline Simpson index & \multicolumn{2}{|c|}{2.102} & \multicolumn{2}{|c|}{5.317} & \multicolumn{2}{|c|}{3.03} & \multicolumn{2}{|c|}{4.29} & \multicolumn{2}{|c|}{2.378} & \multicolumn{2}{|c|}{2.832} & 5.064 \\
\hline
\end{tabular}

The diversity of small mammals according to the Shannon index was 0.786 and the Simpson index - 5.575. The highest diversity was reported at forest edge and agrocenosis, whereas the lowest in the forest (tab. 3).

The average multiannual capture index was $15.53 \%$. In 2017 the index was $17.81 \%$ and practically similar values were regisered in 2018 and 2019 making up $12.81 \%$ and $12.91 \%$ respectively. The highest multiannual average catch index was recorded at the forest edge (43.88\%), and the lowest index was reported in the paludous biotope $-11.22 \%$ (tab.3).

The species A. sylvaticus, A. flavicollis and A. agrarius are the most spread and dominant in various types of biotopes: A. sylvaticus was dominant in paludous biotope $\left(\mathrm{I}_{\mathrm{d}}-58.88 \%\right)$, A. flavicollis was dominant in forest $\left(\mathrm{I}_{\mathrm{d}}-56.64 \%\right)$, at forest edge $\left(\mathrm{I}_{\mathrm{d}}-36,93 \%\right)$ and forest belt $\left(\mathrm{I}_{\mathrm{d}}-39.78 \%\right)$. A agrarius had dominant ecological significance in forest and paludous biotopes. A. uralensis and M. spicilegus were largely distributed with a frequency of $80 \%$. A. uralensis was most abun- dant and dominant in agrocenosis $\left(\mathrm{I}_{\mathrm{d}}-44.08 \%\right)$ M. spicilegus - in agrocenosis and forest belt with eudominant ecological significance. The vole $C$. glareolus had a frequency of $60 \%$ and showed a dominant and eudominant significance in forest biotopes.

The field voles had recedent significance in agrocenosis, paludous and shelter belts. The hygro- philous species M. minutus, $R$. norvegicus and $A$. terrestris were registered only in paludous biotopes with recedent significance (tab. 3; fig.1).

In the northern area, in 5 species of small mammals of 15 registered specific antibodies to Leptospire spp. were detected. The highest share belonged to the species A. agrarius, which constituted $57.14 \%$, followed by C. glareolus $-21.43 \%$, while A. sylvaticus, A. flavicollis and Microtus sp. had equal share $-7.14 \%$ (fig. 2). Two serological groups were highlighted: L. icterohaemorrhagiae and $L$. pomona in equal shares of $50 \%$. The serogroup L. grippotyphosa was hosted by the species A. agrarius, Microtus sp. and C. glareolus, and L. pomona - by A. sylvaticus, A. flavicollis and $A$. agrarius. Only in A. agrarius were detected both serological groups. The presence of the natural outbreak of leptospirosis in the forest ecosystem located near Hijdieni village of Glodeni district has been established with the involvement of $A$. sylvaticus and A. agrarius species. Another outbreak of leptospirosis was reported in paludous ecosystems, agrocenoses and ruralpaludous ecotone near Hadarauti, Cores-tauti and Valcinet localities of Ocnita district with the involvement of the species A. agrarius, C. glareolus and Microtus sp.

In the central area among identified 13 species in the epizootic process were involved A. agrarius, $M$. spicilegus, $R$. norvegicus and $S$. araneus. The highest carrier rate among Leptospira-positive animals belongs to A. agrarius (60.0\%), M. spici- 
legus - 20.0\%, R. norvegicus and S. araneus $10.0 \%$ per each (fig.2). 2 serological groups were found: L. icterohaemorrhagiae $-90 \%$ and L. grippotyphosa - $10 \%$. The serogroup L. icterohaem- orrhagiae was hosted by the species A. agrarius, $M$. spicilegus, $R$. norvegicus and $S$. araneus, and $L$. grippotyphosa by one species - A. agrarius. Both serological groups were detected in A. agrarius.

Table 3. Abundance (\%), ecological significance (Wa) and diversity of small mammal species in studied ecosystems from the southern area of the Republic of Moldova.

\begin{tabular}{|c|c|c|c|c|c|c|c|c|c|c|c|c|}
\hline \multirow{2}{*}{ No. } & \multirow{2}{*}{ Species } & \multicolumn{2}{|c|}{ Forest } & \multicolumn{2}{|c|}{ Agrocenosis } & \multicolumn{2}{|c|}{ Paludous } & \multicolumn{2}{|c|}{ Forest edge } & \multicolumn{2}{|c|}{ Shelter belt } & \multirow{2}{*}{$\begin{array}{c}\text { Total } \\
\text { A }\end{array}$} \\
\hline & & $\mathrm{A}$ & $\mathrm{Wa}$ & $\mathrm{A}$ & $\mathrm{Wa}$ & $\mathrm{A}$ & Wa & A & $\mathrm{Wa}$ & $\mathrm{A}$ & $\mathrm{Wa}$ & \\
\hline 1 & S. araneus & 1.89 & 1.13 & 9.23 & 5.54 & 7.69 & 4.62 & - & - & - & - & 4.26 \\
\hline 2 & A. sylvaticus & 5.66 & 5.66 & 23.08 & 23.08 & 41.76 & 41.76 & 20.78 & 20.78 & 20.93 & 20.93 & 24.62 \\
\hline 3 & A. flavicollis & 64.15 & 64.15 & 16.92 & 16.92 & 4.40 & 4.40 & 24.68 & 24.68 & 37.21 & 37.21 & 25.53 \\
\hline 4 & A. uralensis & - & - & 32.31 & 25.85 & 20.88 & 16.70 & 20.78 & 16.62 & 9.30 & 7.44 & 18.24 \\
\hline 5 & A. agrarius & 22.64 & 22.64 & 1.54 & 1.54 & 13.19 & 13.19 & 5.19 & 5.19 & 9.30 & 9.30 & 10.03 \\
\hline 6 & M. spicilegus & - & - & 15.38 & 12.31 & 4.40 & 3.52 & 14.29 & 11.43 & 2.33 & 1.86 & 7.90 \\
\hline 7 & R. norvegicus & - & - & - & - & 1.10 & 0.22 & - & - & - & - & 0.30 \\
\hline 8 & M. minutus & - & - & - & - & 2.20 & 0.44 & - & - & - & - & 0.61 \\
\hline 9 & Microtus sp. & - & - & 1.54 & 0.92 & 2.20 & 1.32 & 1.30 & 0.78 & - & - & 1.22 \\
\hline 10 & A. terrestris & - & - & - & - & 2.20 & 0.44 & - & - & - & - & 0.61 \\
\hline 11 & C. glareolus & 5.66 & 3.40 & - & - & - & - & 12.99 & 7.79 & 20.93 & 12.56 & 6.69 \\
\hline \multicolumn{2}{|c|}{ Capture index, \% } & \multicolumn{2}{|c|}{19.06} & \multicolumn{2}{|c|}{16.21} & \multicolumn{2}{|c|}{11.22} & \multicolumn{2}{|c|}{14.50} & \multicolumn{2}{|c|}{43.88} & 15.53 \\
\hline \multicolumn{2}{|c|}{ Shannon index } & \multicolumn{2}{|c|}{0.63} & \multicolumn{2}{|c|}{0.843} & \multicolumn{2}{|c|}{0.752} & \multicolumn{2}{|c|}{0.9} & \multicolumn{2}{|c|}{0.866} & 0.786 \\
\hline \multicolumn{2}{|c|}{ Simpson index } & \multicolumn{2}{|c|}{2.18} & \multicolumn{2}{|c|}{4.837} & \multicolumn{2}{|c|}{4.196} & \multicolumn{2}{|c|}{5.66} & \multicolumn{2}{|c|}{4.426} & 5.575 \\
\hline
\end{tabular}

The activation of the natural outbreak of leptospirosis has been reported in forests, paludous ecosystems and in agrocenoses located near Danceni vill., Ialoveni ds., being a possible infectious area for 2 leptospirosis patients in autumn 2018. Compared to the northern and southern areas, the leptospirosis outbreak was active only in the central area for two consecutive years 2018-2019.

In the southern area among 11 species in $R$. norvegicus and $A$. terrestris specific antibodies to L. icterohaemorrhagiae $(100 \%)$ were determined in equal shares - 50\% (fig.2). The outbreak of leptospirosis was reported in paludous ecosystems of Prut meadow, near Cahul town in 2018. In September 2008 (Cahul, Prut meadow), the species $A$. agrarius and $A$. uralensis were detected with the serotypes L. grippotyphosa and $L$. pomona. Over a decade of monitoring, there is an active leptospirosis outbreak, being substituted by leptospira serotype.

Thus, in 9 species of small mammals from 17 collected specific antibodies to Leptospira spp. were found. The presence of leptospires was determined in $4.10 \%$ of total investigated small mammals. In the northern area, positive results were registered in $3.39 \%$, in the central area $5.88 \%$ and in the southern area $-4.0 \%$ (fig. 2). The highest rate belonged to the species $A$. agrarius (53.85\%) and C. glareolus (11.54\%), followed by $M$. spicilegus and $R$. norvegicus (7.69\% each) and equal weight - A. sylvaticus, $A$. flavicollis, Microtus sp., A. terrestris and S. araneus $(3.85 \%$ each). The presence of 3 serogroups were determined in small leptospira-infected mammals, viz. L. icterohaemorrhagiae, L. grippotyphosa and L. pomona. The results obtained indicate a great diversity of species involved in the epizootic process of leptospirosis in the country's ecosystems.

\section{DISCUSSIONS}

Leptospirosis is one of the most common zooanthroponoses in the Republic of Moldova, being a nosology, first diagnosed in humans and reported in $1963(9,24,25)$. The primary detailed study (1950-1960) of the peculiarities of leptospirosis was preceded by determining the cases of disease in cattle registered in Tiraspol (1950). Subsequently, in 1970-1990, this disease was registered in pigs, cattle and horses from all districts $(9,24,25)$.

In the Republic of Moldova, there are 2 types of leptospirosis foci: natural and anthropogenic (9, $23,27,28,29$ ). Currently, the obtained study results confirm the existence of natural and anthropogenic foci of leptospirosis. However, a larger part of the natural ecosystems of the coun- 
try underwent major anthropic changes, this excludes the possibility of strict delimitation of natural foci of leptospirosis from anthropogenic ones. Therefore, in the leptospirosis foci in Moldova the reservoir of infection is the species of the orders Rodentia and Insectivora $(9,10,20$ 23, 27-29). The present study obtained similar data. Thus, during the study period, 13 rodent and 4 insectivore species were determined on the territory of the country, and 9 of them showed positive results to Leptospira spp. Most of the listed species are widespread in the studied ecosystems $(9,10,27-29)$. The results obtained on the diversity of small mammal populations, including species involved in the epizootic process, showed a decreasing tendency, which correspond to other published study results $(9$, $10,20-23,27,28,30,31,32$ ).

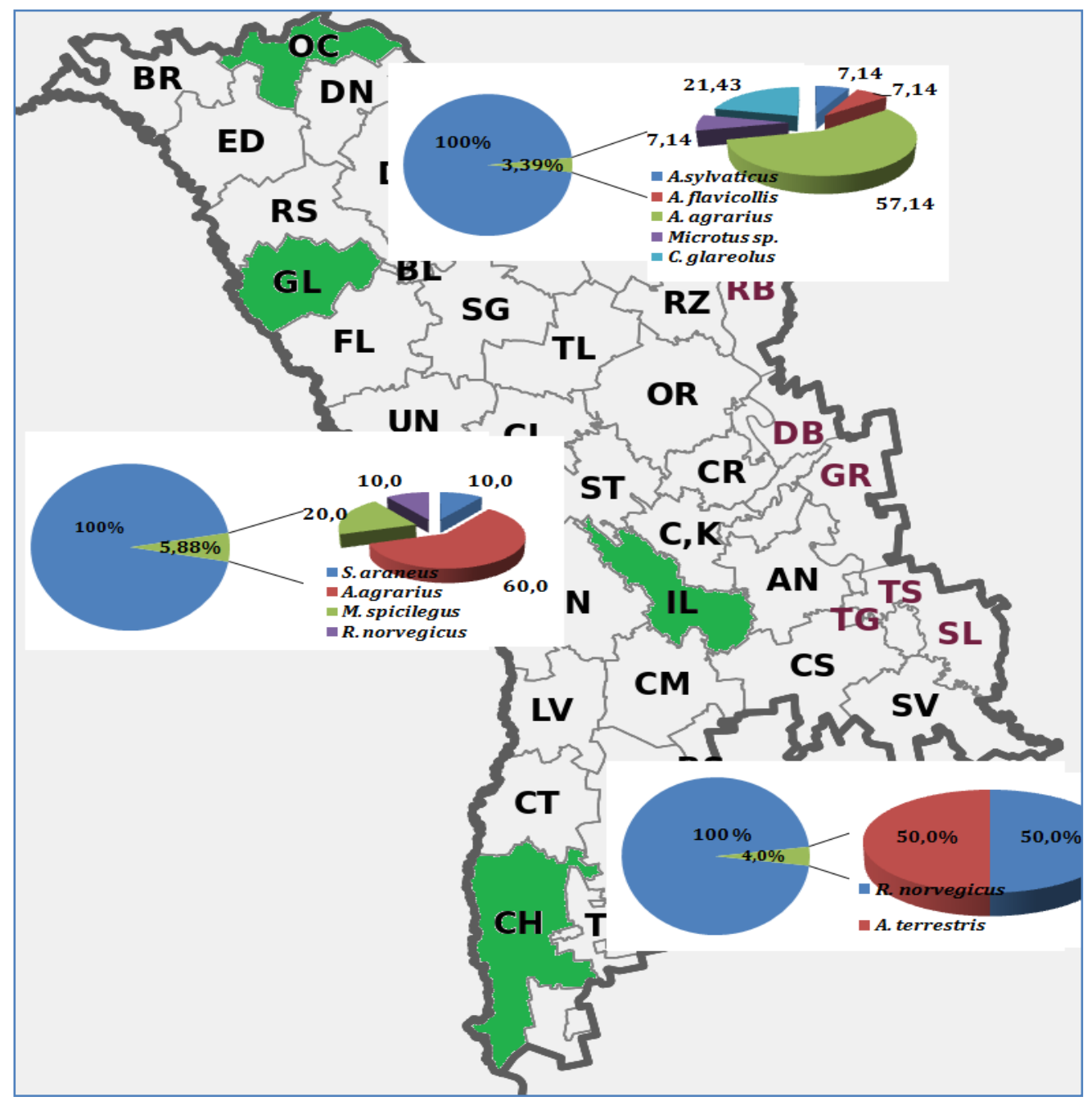

Figure 2. Share (\%) and diversity of small mammal species found with leptospires in northern, central and southern areas of the Republic of Moldova.

An important role in the formation of leptospirosis foci belongs to the species reported as leptospirosis carriers, such as A. sylvaticus, A. flavicollis and $A$. agrarius, which are widely distributed, abundant and dominant in most of the ecosystems of the country. The obtained results confirm the importance of these species as reservoirs that maintain the etiological agent in the environment $(9,10,27-29)$; however not all the aforementioned species are leptospira carriers
(12). The analysis of the etiological structures of leptospires during the period 2017-2019 showed a lower diversity of serogroups (L. grippotyphosa, L. icterohaemorrhagiae, L. pomona) compared to 11-13 serogroups detected in previous studies $(9,10,20,21)$.

The obtained data confirm the relatively intense circulation of the causative agent of leptospirosis in small mammal populations. Human infection occurs accidentally during direct contact with 
objects from the environment, contaminated with the urine of leptospira-carrier small mammals. Some authors claim that the level of morbidity from leptospirosis is influenced by floodrelated outbreaks, recreational activities such as bathing in unauthorized water basins, boating or other water sports, as well as the tendency of disease urbanisation $(3,13,33-36)$. In many countries, leptospirosis is considered an occupational disease previously encountered in farmers and agricultural workers $(33,37)$. Leptospirosis is recognized as a potential hazard in water sports or other recreational activities related to the exposure of the population to potentially contaminated water sources (3). In the Republic of Moldova, during 2017-2019, a total of 15 cases of leptospirosis disease were reported, registered in 8 administrative territories. A higher number of cases of disease were reported mainly in the northern districts: Briceni -5 cases,
Drochia - 2, Soroca, Edinet and Floresti - 1 case each; followed by the central area: Chisinau city - 3, Ialoveni - 1 case and the southern area: Tiraspol city - 1 case (38). In addition to some of the mentioned factors, leptospirosis morbidity in Moldova is determined by non-compliance with hygiene rules for people with high risk of contracting the disease, by consuming products kept in poor conditions, as well as through rodent and other animal urine - contaminated water etc.

Based on the aforementioned, we can conclude that in the current conditions of the Republic of Moldova all key elements persist for the formation and activation of natural foci of leptospirosis such as biotic, abiotic environmental factors, ecological characteristics of the reservoir, the causative agent of leptospirosis and as a result the risk of spreading this disease in the human population.

\section{CONCLUSIONS}

1. 1617 small mammals were collected from the ecosystems of the Republic of Moldova that belong to 13 species of the order Rodentia and 4 of the order Soricomo rpha. The greatest diversity of species was registered in the northern area: 11 rodents, 4 insectivores; center - 11 and 2 respectively; south -9 and 2 respectively. The most widespread and euritope species are A. sylvaticus, A. flavicollis and A. agrarius, found in all areas of the country.

2. Of the 17 small mammal species 9, showed positive serological results for Leptospira spp. (A. agrarius, $C$. glareolus, $M$. spicilegus, $R$. norvegicus, A. sylvaticus, A. flavicollis, Microtus sp., A. terrestris, $S$. araneus), which proves a great diversity of species involved in the epizootic process in leptospirosis. The highest rate belongs to the species A. agrarius (53.85\%) and C. glareolus. The presence of leptospires was determine in $4.10 \%$ of small mammals studied. The highest rate was determined in the central area (5.88\%), the southern area (4.0\%) and the northern area (3.39\%). Among the leptospirosis-carrier species, A. sylvaticus, A. flavicollis, A. agrarius have a wide distribution (F-100\%) and high values of the dominance and abundance index in all the studied ecosystems.

3. In the northern area, the presence of natural leptospirosis foci has been established in forests, paludous, agrocenoses and the rural-marsh ecotone with the involvement of A. flavicollis, A. sylvaticus, $A$. agrarius species, C. glareolus and Microtus sp. The presence of 2 serogroups L. grippotyphosa and L. pomona was determined; both serogroups being detected in A. agrarius.

4. In the central area, the presence of natural leptospirosis foci was established in forests, paludous biotopes and agrocenoses. The main species involved were A. agrarius, M. spicilegus, $R$. norvegicus and S. araneus. The presence of 2 serogroups was determined: L. icterohaemorrhagiae and L. grippotyphos; both serogroups were detected in A. agrarius.

5. In the southern area the presence of the natural outbreak of leptospirosis in thepaludous ecosystems with the involvement of $R$. norvegicus and A. terrestris species has been established. Antibodies specific to the serotype L. icterohaemorrhagiae were determined in both species.

6. The study of the leptospira circulation in the environment and in the population of small mammals allows the prediction of the epizootological situation and the risk of spreading this disease in the human population in the Republic of Moldova. 


\section{CONFLICT OF INTERESTS}

The author does not declare any conflict of interest.

\section{ACKNOWLEDGEMENTS}

The author is grateful to dr. Victoria Nistreanu and dr. Natalia Caterinciuc for valuable comments and suggestions, and for improving the English text of the paper. The study was performed within the doctoral project, State Program project 20.80009.7007.02 and within collaboration contract between the Institute of Zoology and the National Agency for Public Health.

\section{REFERENCES}

1. Ellis WA. Leptospiroza. In: Palmer SR, Soulsby L. Simpson DIH. (eds.) Zoonoze. Editura Știinţelor Medicale. Bucureşti; 2005. p.115-129.

2. Bharti AR, Jarlath EN, Ricaldi JN, Matthias MA, Diaz MM, Lovett MA, et al. Leptospirosis: A zoonotic disease of global importance. Lancet Infect. Dis. 2003;12:757-771.

3. Ricaldi JN, Vinetz JM. Leptospirosis in the tropics and in traveler. Current Infectious Disease Reports. 2006;8(1):51-58.

4. Vijayachari P, Sugunan AP, Shriram AN. Leptospirosis: an emerging global public health problem. $J$ Biosci. 2008;33(4):557-569.

5. Wasiński B, Dutkiewicz J. Leptospirosis - current risk factors connected with human activity and the environment. Ann Agric Environ Med. 2013;20(2):239-244.

6. Desvars A, Cardinale E, Michault A. Animal leptospirosis in small tropical areas. Epidemiol Infect. 2011;139(2):167-88.

7. Kenneth Boey, Kanae Shiokawa, and Sreekumari Rajeev. Leptospira infection in rats: A literature review of global prevalence and distribution. PLoS Negl Trop Dis. 2019;13(8): e0007499.

8. Ellis WA. Animal Leptospirosis In: Adler B. (eds.) Leptospira and Leptospirosis. Heidelberg: Springer Berlin Heidelberg; 2015. p. 99-137.

9. Toderash IK, Kiku VF, Uspenskaia IG, Movile AA, Georgitsa SD, Burlaku VI, et al. Prirodnaia ochagovost' leptospiroza na territorii respubliki Moldova v sovremennykh usloviiakh [Natural focality of leptospirosis in the territory of the Republic of Moldova in modern conditions]. Buletinul AŞM. Ştiinţele vieții. Chișinău. 2010;3 (312):88-101.

10.Gheorghiță S, Chicu V, Nistreanu V, Burlacu V, Guţu A, Melnic V, et al. The role of micromammals in maintenance the leptospirosis foci in the Republic of Moldova. Oltenia Journal for studies in Natural Sciences. Craiova, 2009;25: 291-296.
11. World Health Organization. Human leptospirosis: guidance for diagnosis, surveillance and control. WHO Library Cataloguing-in-Publication, 2003; 122.

12. Bunnell JE, Hice CL, Watts DM, Montrueil V, Tesh RB, Vinetz JM. Detection of Pathogenic Leptospira spp. Infections Among Mammals Captured in the Peruvian Amazon Basin Region. Am J Trop Med Hyg. 2000;63(5-6):255 - 8.

13. Vieira ML, Gama-Simoes MJ, Collares-Pereira M. Human leptospirosis in Portugal: a retrospective study of eighteen years. International Journal of Infectious Diseases. 2006;10:378-386.

14. Nistreanu V, Savin A, Larion A, Sîtnic V, Chihai O. Ecological aspects of rodent communities in agrarian ecosystems of Moldova. Bulletin of University of Agricultural Sciences and Veterinary Medicine ClujNapoca. 2011;68: 272-276.

15. Burlacu V, Gheorghita S, Caraman N, Nistreanu V, Larion A, Cirlig T. Faunistic and ecological peculiarities of small mammal reservoir species in the northern zone of the Republic of Moldova. Actual problems of protection and sustainable use of the animal world diversity: VII-th International conference of zoologists. 2013; 34-35.

16.Savin A, Nistreanu V. Structural - functional transformations of rodent communities in ecosystems of Moldova against a background of anthropogenic and climatic changes. Oltenia Journal for studies in Natural Sciences. Craiova. 2009; 25:275-280.

17.Sîtnic V, Munteanu A. Distribuția biotopică a speciilor Microtus arvalis Pall. și Microtus rossiaemeridionalis Ogn. (Rodentia, Cricetidae) în Republica Moldova. Simpozion international „Diversitatea, valorificarea rațională și protecția lumii animale”. Chișinău, 2009; 106-109.

18. Ruvoen-Clouet N, Menard A, Sonrier C, Fillonneau C, Rakotovao F, Ganière JP, et al. Role of the Coypu (Myocastor coypus) in the epidemiology of leptospirosis in domestic animal and humans in France. European Journal of Epiedmiology. 2001;17(2):111-21.

19.Jansen A, Nöckler K, Schönberg A, Luge E, Ehlert D, Schneider T. Wild boars as possible source of hemorrhagic leptospirosis in Berlin, Germany. Eur J Clin Microbiol Infect Dis. 2006; 25(8): 544-6.

20.Culibacinaia E, Moraru D, Mihailenco A, Melnic V. Structura etiologică a focarelor naturale de leptospiroză în ultimul deceniu în Republica Moldova. Congresul IV al igieniștilor, epidemiologilor, microbiologilor și parazitologilor din Republica Moldova. Chişinău, 1997;2(b): 23-24.

21. Magdei M, Moraru D, Culibacinaia E, Mihailenco A, Guţu A, Melnic V. Leptospiroza în Republica Moldova în anii 1995-1997. Materialele conferinţei știinţificăanuală. Chişinău, 1999; 168-169.

22. Belous AM, Mikhailenko AG, Untura AA. Nekotorye voprosy prirodnoi ochagovosti leptospirozov v Moldavskoi SSR [Some questions of the natural focus of leptospirosis in the Moldavian SSR]. XII Vsesoiuznaia 
konferentsiia po prirodnoi ochagovosti boleznei. Novosibirsk. 1989; 20-21. Russian.

23. Kotsofane VA, Roshka MP, Prisakar' VI, Kulbachnaia EV. Opisanie antropurgicheskogo ochaga leptospiroza [Description anthropurgic outbreak of leptospirosis]. Problemy Epidemiologii, Microbiologii i Parazitologii. Tezisy dokladov II S'ezda Gigienistov i sanitarnykh vrachei, mikrobiologov, epidemiologov $i$ parazitologov Moldavskoi SSR. Kishinev. 1987; 300301.

24. Prisakar' VI. Epidemiologicheskii nadzor za leptospirozami [Epidemiological surveillance of leptospirosis]. Shtiintsa. Kishinev; 1993. p. 5-9.

25. Syrbu V. K etiologii i epidemiologii leptospirozov v Moldavii [To the etiology and epidemiology of leptospirosis in Moldova]. Zdravookhranenie. Kishinev; 1964. c. 30-32.

26. Chicu V, Gheorghiţa S, Burlacu V, Guţu A, Culibacinaia E, Melnic V, et al. Colectarea, evidenţa şi pronosticarea numărului mamiferelor mici în anumite teritorii [Collection, recording and prediction of the number of small mammals in certain territories]. Indicaţie metodică. Chişinău. 2012; 52.

27. Burlacu V, Caterinciuc N, Nistreanu V, Larion A, Gheorghița S, Guţu A, et al. Particularităţile ecologice şi epizootologice ale mamiferelor mici şi rolul lor în formarea şi menţinerea focarelor naturale şi antropurgice de leptospiroză în zona de nord a Republicii Moldova [The ecological and epizootological peculiarities of small mammals and their role in the formation and maintenance of natural and anthropurgic outbreaks of leptospirosis in the northern part of the Republic of Moldova]. Buletinul Academiei de Stiinţe a Moldovei. Stiinţe medicale. 2017; 1(53): 50-54.

28. Caterinciuc N, Burlacu V, Nistreanu V, Larion A, Gheorghița S. Structure of small mammal faunistic complex in leptospirosis foci and epidemiological aspects of disease. Studii și Comunicări. Complexului Muzeal de Ştiințele Naturii Ion Borcea, Bacău, Romania. 2016-2017; 26:68-73.

29. Burlacu V, Caterinciuc N, Nistreanu V, Larion A. Epozootological monitoring of leptospirosis and tularemia in small rodent population (Mammalia:
Rodentia) in the Republic of Moldova. Biology and Sustainable Development. Romania, Bacau. 2019; 4041.

30.Tikhonov IA, Muntyanu AI, Uspenskaya IG, Konovalov YN, Burlaku VI, Karaman NK, et al. Biotopic distribution, population structure, and some features of small mammal reproduction in Chisinau City. Biology Bulletin. 2012;39 (10):39-845.

31. Burlacu V, Nistreanu V, Larion A, Caterinciuc N. Particularităţile faunistice şi ecologice ale micromamiferelor în zona de nord a Republicii Moldova. Eco-TIRAS International Association of River Keepers Leo Berg Educational Foundation the City of Bender Museum. Collection of Scientific Articles. 2016; 65-69.

32. Burlacu V, Nistreanu V, Larion A, Caterinciuc N. Structura comunităților de mamifere mici (Rodentia, Soricomorpha) în agrocenozele zonei de nord a Republicii Moldova. Buletinul Academiei de Stiinţe a Moldovei. Ştiinţele vieţii. 2018; 1(334):126-133.

33. Levett PN. Leptospirosis. Clinical Microbiology Reviews. 2001;14 (2):296-326.

34. Mezentsev VM, Briukhanova GD, Efremenko VI, Kovalev NG, Kalashnikov IA, Grizhebovskiĭ GM. Leptospirosis in the Southern Federal District of the Russian Federation. Zh Microbiol Epidemiol Immunobiol. 2003;(6):63-7.

35. Masashi N, Shigeki F, Haake DA, Paterson DL. Leptospirosis after recreational exposure to water in the Yaeyama Islands, Japan. Am J Trop Med Hyg. 2005;73(4):652-656.

36.Pappas G, Papadimitriou Ph, Siozopoulou V, Christou L, Akritidis N. The globalization of leptospirosis: worldwide incidence trends. Int $J$ Infect Dis. 2008;12(4):351-7.

37. Jansen A, Schöneberg I, Frank Ch, Alpers K, Schneider Th, Starket K. Leptospirosis in Germany, 19622003. Emerg Infect Dis. 2005; 11(7):1048-1054.

38. Caterinciuc N, Guțu A, Slivinschi S. Infecțile zooantroponoze [Zooanthroponosis infections]. In: Bahnarel I, Șalaru I, Spînu P, et al.(eds.). Supravegherea de Stat a sănătăţii publice în Republica Moldova (Raport Național 2017); Chișinău, 2018. p.36-40.
Date of receipt of the manuscript: $22 / 07 / 2020$
Date of acceptance for publication: $12 / 08 / 2020$

Victoria BURLACU, ORCID 0000-0002-8828-1585 